\author{
Marta PALECZNA \\ Uniwersytet Jagielloński w Krakowie \\ marta.paleczna@doctoral.uj.edu.pl
}

\title{
PRZEKŁAD USTNY W PAŃSTWOWYM MUZEUM AUSCHWITZ-BIRKENAU (PMAB): WARUNKI PRACY, PROBLEMY I PROFIL TŁUMACZA
}

ABSTRACT Interpretation at The Auschwitz-Birkenau Memorial and Museum (ABMM): Working Conditions, Problems and Interpreter's Profile

In 2016 The Auschwitz-Birkenau Memorial and Museum was visited by over 2 million people, of whom over 400 thousand were Polish speakers. The others, over 1.5 million people, heard about the history of the camp from guides speaking their native languages. The largest group consisted of tourists from Great Britain, the United States, Italy, Spain, Israel and Germany. Due to the constantly increasing number of foreign tourists, the ABMM had to face the problem of shortage of guides speaking particular languages. Thus, a more and more popular solution is hiring interpreters who, along with Polish-speaking guides, provide the history of the camp to foreign language tourists. The time of sightseeing the ABMM with a guide is limited, therefore quick decision making regarding the interpretation is of the crucial importance. Basing on surveys carried out among interpreters I would like to present the interpretation at the Auschwitz Museum as an example of intercultural dialogue. Problems which interpreters are faced with and the way these problems are approached have a tremendous impact on the reception of the heard history.

Key words: interpretation, The Auschwitz-Birkenau Memorial and Museum, interpreter 


\section{UWAGI WSTĘPNE}

$\mathrm{Na}$ krakowskich uczelniach studenci neofilologii często bywają zapraszani do podjęcia pracy w charakterze tłumaczy w Państwowym Muzeum Auschwitz-Birkenau. Niniejszy artykuł stawia sobie za cel opis warunków pracy, profilu oraz problemów tłumacza przekładającego informacje udzielane przez licencjonowanego przewodnika (zwanego Edukatorem) na potrzeby grup obcojęzycznych gości. Może okazać się przydatny studentom rozważającym podjęcie takiej pracy oraz badaczom przekładu. Istnieją już opracowania historii przekładu na potrzeby administracji państwem, dyplomacji, działań zbrojnych, ewangelizacji, odkrywania świata, podboju i ekspansji kolonialnej ${ }^{1}$, brak jest jednak, o ile nam wiadomo, opracowań dotyczących tłumaczenia na potrzeby turystów, których liczba stale i szybko rośnie. Jedyne znane nam publikacje tego rodzaju dotyczą tłumaczeń dla pielgrzymów². Temat tłumaczenia informacji o nazistowskich obozach był poruszany m.in. przez Degen ${ }^{3}$, która analizowała tłumaczenie nagrań relacji świadków Zagłady Żydów, czy Kuhiwczaka ${ }^{4}$, który zajmował się problemem przekazywania informacji o Holokauście od strony językowej. Badacze przekładu starają się zwrócić uwagę na rolę, jaką odgrywają tłumacze w sytuacji konfliktu czy wojny'. Tematem tym zajmowali się m.in.: Apter, Dragovic-Drouet, Inghilleri, Stahuljak ${ }^{6}$. W czasie II wojny światowej na terenie obozu

Por.J. Baigorri Jalón, La interpretación de conferencias. El nacimiento de una profesión, de París a Núremberg, Granada 2000; D. Gile, Basic Concepts and Models for Interpreter and Translator Training, Amsterdam-Philadelphia 1995; M. Lederer, La traduction simultanée. Fondements théoriques, Paris 1981; B. Moser-Mercer Quality in Interpreting: Some Methodological Issues, „The Interpreters' Newsletter” 1996, nr 7; F. Pöchhacker, Introducing Interpreting Studies, London-New York 2004; Translation Studies. Perspectives on an Emerging Discipline, red. A. Riccardi, Cambridge 2002; M. Tryuk, Przektad ustny środowiskowy, Warszawa 2006; taż, Przektad ustny konferencyjny, Warszawa 2007.

2 M. Chrobak, Ttumacze pielgrzymów, [w:] tejże, Między światami. Ttumacz ustny oraz komunikacja międzykulturowa w literaturze odkrycia i konkwisty Ameryki, Kraków 2012.

3 S. Degen, The Illusion of Authenticity: The Translation of Video Testimonies with Survivors of National Socialist Terror for Use in Education Work, [w:] Interpreting in Nazi Concentration Camps, red. M. Wolf, London 2016.

4 P. Kuhiwczak, Intertwining Memory and Translation. The Grammar of Survival. How do We Read Holocaust Testimonies, [w:] Translating and Interpreting Conflict, red. M. Salama-Carr, Amsterdam-New York 2007.

5 H. Footitt, M. Kelly, Languages at War. Policies and Practices of Language Contacts in Conflict, Basingstoke 2012, s. 2.

6 E. Apter, Against World Literature. On the Politics of Untranslatability, London 2013; M. Dragovic-Drouet, The Practice of Translation and Interpreting during the Conflicts in the Former Yugoslavia (1991-1999), [w:] Translating and Interpreting Conflict, red. M. Salama-Carr, Amsterdam-New York 2007; M. Inghilleri, The Ethical Task of the Translator in the Geo-Political Arena: From Iraq to Guantánamo Bay, „Translation Studies” 2008, vol. 1, nr 2; Z. Stahuljak, Violent Distortions: Bearing Witness to the Task of Wartime Translators, „TTR: Traduction, Terminologie, Rédaction” 2000, vol. 13, nr 1; taż, War, Translation, Transnationalism: Interpreters in and of the War (Croatia, 19911992), [w:] Critical Readings in Translation Studies, red. M. Baker, London 2010. 
Auschwitz-Birkenau istnieli również tłumacze ustni, a charakter i warunki ich pracy badały Tryuk i Wolf?

Badanie przeprowadzone wśród tłumaczy pracujących na terenie PMAB pozwoliło przyjrzeć się warsztatowi tłumacza i zbudować pewien ogólny jego profil oraz określić rolę, jaką pełni on w dialogu międzykulturowym. Tryuk ${ }^{8}$, odwołując się do Pyma ${ }^{9}$, zaznacza, iż: Przedmiotem badań translatoryki nie powinien być tekst przektadu, jego kontekst ani nawet jego cechy jezykowe, lecz ttumacz, żywy cztowiek, gdyż to na niego spada odpowiedzialność za dziatalność spoteczna, jaka jest przektadanie. Żeby zrozumieć, dlaczego jakiś tekst jest przektadany, trzeba przyjrzeć się ludziom, którzy to robia. To wtaśnie dzięki ttumaczowi, otoczeniu spotecznemu, na które sktadają sie jego klienci, mecenasi, czytelnicy, stuchacze przektadu, możemy zrozumiec, dlaczego pewne przektady powstaja $w$ danym czasie i miejscu. Thumaczenie wykonywane dla obcojęzycznych zwiedzających można uznać za odmianę tłumaczenia środowiskowego ${ }^{10}$. Według Matej encyklopedii przektadoznawstwa ${ }^{11}$ thumaczenie środowiskowe to ttumaczenie bilateralne, zdanie po zdaniu, bez notatek, np. na zebraniach, w sytuacji wielojezyczności, w negocjacjach, gdy ttumacz nie tylko przekazuje treść wypowiedzi, ale także może interweniować (wypowiadać wtasne zdanie czy stosować modyfikacje, np. skróty lub zmiany rejestru); również w dyplomacji, turystyce, na użytek imigrantów ${ }^{12}$.

W analizowanym przypadku głównym celem wykonywanego tłumaczenia jest edukacja grup obcojęzycznych. Należy podkreślić, iż w badaniu wzięli udział tłumacze, którzy pracują ze zwiedzającymi PMAB, nie są to natomiast jedyni tłumacze pracujący na terenie byłego obozu Auschwitz-Birkenau. Tłumacze ustni pojawiają się także na przykład w czasie ważnych uroczystości, jak chociażby coroczne obchody rocznicy wyzwolenia obozu. Dr Piotr M.A. Cywiński, dyrektor Muzeum, na oficjalnej stronie internetowej w ten sposób opisuje celowość istnienia PMAB: $W$ czasach, w których odradzaja siępopulizmy, wzmacnia sięnieufność i znieczulica względem potrzebujacych, zanika zdolność reagowania na zto, na ludobójcze konflikty i śmierć, a także rośnie lęk przed wszystkim, co inne, powracaja obrazy zorganizowanej ideologicznie nienawiści, pogardy, rasizmu i antysemityzmu. Nigdy bardziej Europa i Świat nie potrzebowaty jasnego świadectwa ptynacego $z$ najciemniejszych kart swojej wtasnej historii ${ }^{13}$.

M. Tryuk, Interpreting and Translating in Nazi Concentration Camps during World War II, „Linguistica Antverpiensia. New Series: Themes in Translation Studies" 2016, nr 15, s. 52-86; Interpreting in Nazi...

8 M. Tryuk, „Ty nic nie mów, ja będę ttumaczyl”. O etyce w ttumaczeniu ustnym, Warszawa 2012, s. 23.

9 A. Pym, Humanizing Translation History, „Hermes. Journal of Language and Communication Studies" 2009, nr 42, s. 30.

10 M. Tryuk, Przektad ustny środowiskowy; taż, O ttumaczach, prawnikach, lekarzach i urzędnikach. Teoria i praktyka ttumaczenia środowiskowego w Polsce, Warszawa 2010.

11 Mata encyklopedia przektadoznawstwa, red. U. Dąmbska-Prokop, Częstochowa 2000, s. 261-262.

12 M. Tryuk, Przektad ustny środowiskowy, s. 8.

13 Sprawozdanie 2016, red. B. Bartyzel, P. Sawicki, Oświęcim 2017, Auschwitz-Birkenau. Były Niemiecki Nazistowski Obóz Koncentracyjny i Zagłady, [online] http://www.auschwitz.org/muzeum/sprawozdania-roczne/. 
W realizacji celów, jakie stawia przed sobą PMAB, biorą również udział tłumacze ustni, którzy, wykonując tłumaczenie wypowiedzi Edukatorów lub wcielając się w Edukatorów, przybliżają obcojęzycznym gościom historię byłego obozu koncentracyjnego i zagłady oraz w ten sposób przyczyniają się do edukacji społeczeństwa.

\section{PAŃSTWOWE MUZEUM AUSCHWITZ-BIRKENAU}

Zapotrzebowanie na pracę tłumaczy ustnych wynika z ciągłego wzrostu zainteresowania Państwowym Muzeum Auschwitz-Birkenau wśród zagranicznych zwiedzających, czego dowodem są dane statystyczne pochodzące $\mathrm{z}$ rocznych sprawozdań muzealnych. Goście mogą wybrać jedną z kilku opcji zwiedzania PMAB, jednak do najpowszechniejszych należą: standardowe zwiedzanie ogólne (grupowe i w tzw. turach) oraz zwiedzanie studyjne jedno- lub dwudniowe ${ }^{14}$. Oprócz tego tworzone są programy skierowane do konkretnych grup odbiorców: osadzonych w zakładach karnych, funkcjonariuszy publicznych, oficerów wojsk, przedstawicieli wymiaru sprawiedliwości, lekarzy, artystów itp. Stanowiące integralną część Muzeum Międzynarodowe Centrum Edukacji o Auschwitz i Holokauście, jedno z najważniejszych na świecie - po Instytucie Yad Vashem ${ }^{15}$ - organizuje liczne szkolenia, dyskusje i kongresy tematycz$n e^{16}$. Jak pisze dyrektor PMAB we wstępie do sprawozdania z jego działalności za rok 2016, nigdy bardziej nie potrzebowaliśmy oparcia dla naszych wtasnych osadów i dziatan w gtosach pamięci z tamtych lat. Nigdy bardziej nie potrzebowaliśmy wzmocnienia naszych trudnych wyborów pamięcia o pozostawionych wtasnemu losowi ofiarach Auschwitz i Szoa. Krzyk tamtych ofiar będzie ponadczasowy, o ile dotrze do naszych uszu także i dziś. Dlatego dziś i każdego następnego dnia - być może jak nigdy wcześniej każdy z nas powinien przemyśleć swoja osobista lekcje Auschwitz. Wszyscy potrzebujemy tego rytuatu przejścia ${ }^{17}$.

PMAB zostało utworzone staraniem byłych więźniów obozu, na mocy ustawy polskiego sejmu z 2 lipca 1947 roku. Obejmuje obszar dwóch części byłego obozu koncentracyjnego i zagłady: Auschwitz I (2 ha) i Auschwitz II Birkenau (171 ha). W 1979 roku zostało wpisane na listę światowego dziedzictwa UNESCO jako symbol wszystkich miejsc tego typu ${ }^{18}$. Liczba turystów odwiedzających PMAB rośnie z roku na rok, w 2016 roku po raz pierwszy przekroczyła 2 miliony. Zdecydowana większość z nich wybrała zwiedzanie pod opieką wykwalifikowanego przewodnika, zwanego Edukatorem. Na terenie PMAB pracuje obecnie około 300 Edukatorów ofe-

14 Rodzaje zwiedzania, Auschwitz-Birkenau. Były Niemiecki Nazistowski Obóz Koncentracyjny i Zagłady, [online] http://www.auschwitz.org/zwiedzanie/przewodnicy/.

15 Yad Vashem - The World Holocaust Remembrance Center, [online] http://www.yadvashem.org/.

16 T. Świebocka, J. Pinderska-Lech, J. Mensfelt, Auschwitz-Birkenau. Historia i teraźniejszość, Oświęcim 2010, s. 26.

17 Sprawozdanie 2016, s. 5.

18 Muzeum $w$ datach, Auschwitz-Birkenau. Były Niemiecki Nazistowski Obóz Koncentracyjny i Zagłady, [online] http://www.auschwitz.org/muzeum/historia-muzeum/muzeum-w-datach. 
rujących zwiedzanie w prawie 20 językach (angielski, chorwacki, czeski, francuski, hebrajski, hiszpański, japoński, niderlandzki, niemiecki, polski, rosyjski, serbski, słowacki, szwedzki, węgierski i włoski). Bardzo szybko zmieniająca się frekwencja przyjazdów z różnych obszarów świata, a co za tym idzie, z różnych obszarów językowych, sprawia, iż równie szybko zmienia się zapotrzebowanie na Edukatorów posługujących się danym językiem. Dla porównania, w roku 2016 znacznie wzrosła, w porównaniu z poprzednim rokiem, liczba zwiedzających z Portugalii (o 115\%), Włoch (o 91\%), Hiszpanii (o 68\%), Izraela (o 59\%) oraz Francji (o 44\%), przy liczbie turystów z Polski utrzymującej się na prawie takim samym poziomie. Konsekwencją takiego zjawiska jest stale wzrastające zapotrzebowanie na Edukatorów posługujących się językami obcymi. Jako że ich liczba wciąż jest niewystarczająca, częstą praktyką stosowaną przez obcojęzyczne grupy, w przypadku braku dostępnych przewodników w ich języku, jest rezerwowanie Edukatora oprowadzającego gości w języku polskim oraz zatrudnianie tłumacza, którego zadaniem jest tłumaczenie jego wypowiedzi (grupy azjatyckie z kolei często rezerwują Edukatorów posługujących się językiem angielskim i przyjeżdżają z własnym tłumaczem).

\section{PRZEKŁAD USTNY W PAŃSTWOWYM MUZEUM AUSCHWITZ-BIRKENAU}

Głównym celem wizyty w Państwowym Muzeum Auschwitz-Birkenau jest edukacja, stąd też licencjonowani przewodnicy zwani są Edukatorami. Standardowe zwiedzanie, zarówno w języku polskim, jak i w języku obcym, trwa 3,5 godziny i obejmuje obszar dwóch zachowanych części obozu koncentracyjnego i zagłady: Auschwitz I i Auschwitz II Birkenau. W pierwszej części (Auschwitz I) goście otrzymują słuchawki i odbiorniki, a Edukator mówi do mikrofonu, co pozwala na pewną swobodę: słuchając informacji, zwiedzający nie muszą znajdować się bezpośrednio przy Edukatorze, mogą zatrzymać się na chwilę czy zrobić zdjęcia. Na terenie obozu Birkenau starano się zachować stan zbliżony do oryginalnego, dlatego nie zostały otwarte tam ekspozycje. Grupy podczas zwiedzania nie dysponują sprzętem technicznym, lecz słuchają mówiącego bezpośrednio do nich Edukatora. Większa część wizyty ma charakter monologu, jednakże w każdym momencie goście mogą zadawać pytania, tłumaczenie ma zatem charakter mieszany, na przemian monologu Edukatora oraz dialogów pomiędzy nim a zwiedzającymi.

\section{METODOLOGIA}

Badanie miało charakter ankietowy. Ankieta została sporządzona i przeprowadzona przez autorkę artykułu we wrześniu 2017 roku wśród 10 tłumaczy języka hiszpańskiego, którzy pracują na terenie Państwowego Muzeum Auschwitz-Birkenau, wykonując tłumaczenia informacji przewodnickich i oprowadzając hiszpańskojęzyczne grupy. 
Ze względu na małą próbkę badanie ma charakter pilotażowy, a wyniki mogą być traktowane jedynie jako punkt wyjścia do dalszych badań.

Tłumacze, posiadający staż pracy od 2 do 10 lat, zostali poproszeni o odpowiedź na następujące pytania:

1. Jakie są charakterystyczne elementy rzeczywistości obozowej?

2. Jakie słowa/wyrażenia/zwroty sprawiają największy problem w tłumaczeniu na język hiszpański?

3. Jakie pytania najczęściej zadają zwiedzający w trakcie zwiedzania lub po jego zakończeniu?

4. Jakie czynniki mają największy wpływ na jakość tłumaczenia na terenie PMAB?

5. Jakie czynniki utrudniają pracę thumacza na terenie PMAB?

6. Jakie cechy powinien posiadać tłumacz pracujący na terenie PMAB?

Pytania miały charakter otwarty, a tłumacze odpowiadali na nie, uwzględniając własne doświadczenie zdobyte na terenie PMAB oraz obserwacje poczynione podczas pracy. Udzielone odpowiedzi dotyczące słownictwa zostały przeanalizowane pod względem ilościowym, natomiast odpowiedzi dotyczące czynników wpływających na jakość tłumaczenia, cech tłumacza oraz zadawanych pytań - pod względem jakościowym. Przytoczone odpowiedzi $\mathrm{z}$ ankiet zostały zachowane w formie oryginalnej, w przypadku kilkukrotnego występowania podobnej odpowiedzi został przytoczony tylko jeden przykład.

\section{PRZEKŁAD USTNY NA TERENIE PMAB Z PERSPEKTYWY TŁUMACZY}

\subsection{Tekst}

Jakie są charakterystyczne elementy rzeczywistości obozowej?

\begin{tabular}{l|l}
$\begin{array}{l}\text { Pojęcia pojawiające } \\
\text { się ponad 2 razy }\end{array}$ & apele, pasiaki, komory gazowe, kapo, krematoria \\
$\begin{array}{l}\text { Pojęcia pojawiające } \\
\text { się 2 razy }\end{array}$ & kary, transporty, bloki obozowe, drut kolczasty, szubienica, pociąg \\
$\begin{array}{l}\text { Pojęcia pojawiające } \\
\text { się 1 raz }\end{array}$ & $\begin{array}{l}\text { terror, strach, poniżanie, wyzyskująca praca, brak pożywienia, tortury, śmierć, } \\
\text { zagazowywanie, selekcje, brama wejściowa, kompanie, znęcanie się nad więź- } \\
\text { niami, zdjęcia identyfikacyjne, dyscyplina, SS-mani, Żydzi, język niemiecki, } \\
\text { krzyk, strażnicy, cele, tory, bocznica, rampa, cyklon B, prycze, dół na popiól, } \\
\text { plac apelowy, gód, tłok, choroby, praca ponad siły, celowe zwiększanie śmier- } \\
\text { telności, ludobójstwo }\end{array}$
\end{tabular}


Jakie słowa/wyrażenia/zwroty sprawiają największy problem w tłumaczeniu na język hiszpański?

Pojęcia pojawiające się przynajmniej

2 razy

Pojęcia pojawiające się $1 \mathrm{raz}$ więźniowie funkcyjni, włosianka, cele stojące, buksa

zwroty z języka niemieckiego, różne metody zabijania, winkiel, żydowskie szaty modlitewne, koks, kanalizacja, oczyszczalnia, drut kolczasty, kara słupka, apele, kapo, drewniaki, słownictwo specjalistyczne (np. dotyczące techniki zagłady, procesów sądowych, chorób, zabezpieczeń obozowych), Vorarbeiter

Podając charakterystyczne elementy rzeczywistości obozowej, tłumacze wskazywali te elementy, które składają się dla nich na obraz obozu. Pomimo dużej liczby wymienionych elementów, niewiele z nich można uznać za problematyczne w tłumaczeniu. Tłumacze wskazywali głównie na kilka pojęć z języka specjalistycznego, np. techniki zagłady czy zabezpieczeń obozowych, oraz zwroty z języka obozowego, tzw. Lagersprache $e^{19}$, np. Vorarbeiter czy winkiel. Opisując rzeczywistość obozową, tłumacze często posługiwali się pojęciami ogólnymi, natomiast jako problematyczne wskazywali konkretne przykłady, pochodzące już z języka specjalistycznego. Jako przykład elementu ogólnego może posłużyć cela, natomiast za problematyczne tłumacze uznali pojęcie cela stojąca, podobnie ogólne pojęcie to kara, natomiast konkretne, sprawiające problem w tłumaczeniu jest pojęcie kara stupka. Respondenci zwrócili również uwagę na fakt, że o problematycznym słownictwie można mówić w zasadzie tylko w przypadku pierwszych tłumaczeń wykonywanych na terenie byłego obozu; wielu z nich przygotowując się do kolejnych tłumaczeń, ma już gotowy glosariusz.

\subsection{Nadawca, odbiorca, kontekst}

Jakie czynniki mają największy wpływ na jakość tłumaczenia na terenie PMAB?

\begin{tabular}{l|l}
\hline Tłumacz & - doświadczenie \\
& - umiejętność mówienia do ludzi (dykcja, intonacja, emisja głosu) \\
& - przygotowanie i kultura osobista \\
& - znajomość odpowiedniego słownictwa \\
& - wiedza historyczna (nie tylko o samych obozach, ale i szersze tło) \\
& - ogólna biegłość językowa \\
\hline Edukator & - gotowość Edukatora do współpracy, czy jest sympatyczny, czy mu się spie- \\
& szy, jego zachowanie oraz wsparcie
\end{tabular}

19 Język obozowy, w którym słownictwo niemieckie zostało zaadaptowane do gramatyki i wymowy polskiej. Por. P. Levi, The Drowned and the Saved, London 1988; D. Wesolowska, Stowa z piekta rodem. Lagerszpracha, Kraków 1996; W. Oschlies, „Lagerszpracha”. Zur Theorie und Empirie einer KZ-spezifischen Soziolinguistik, „Zeitgeschichte” 1985, vol. 13, nr 1. 


\begin{tabular}{|l|l|}
\hline Zwiedzający & $\begin{array}{l}\text { - inni zwiedzający w Muzeum, liczba grup na terenie Muzeum } \\
\text { - zachowanie turystów w grupie (czy rozpraszają), nastawienie grupy, dla któ- } \\
\text { rej się tłumaczy, jej oczekiwania }\end{array}$ \\
\hline Czynniki zewnętrzne & $\begin{array}{l}\text { - jakość sprzętu nagłaśniającego (mikrofon i odbiorniki) } \\
\text { - pogoda }\end{array}$
\end{tabular}

Jakie czynniki utrudniają pracę tłumacza na terenie PMAB?

\begin{tabular}{|c|c|}
\hline Czas & $\begin{array}{l}\text { - pośpiech, ograniczenie czasowe } \\
\text { - przestoje }\end{array}$ \\
\hline $\begin{array}{l}\text { Zwiedzający } \\
\text { i Edukatorzy }\end{array}$ & $\begin{array}{l}\text { - ludzie odłączający się od grupy, „niesforni” członkowie grupy (oddalający } \\
\text { się, zatrzymujący się, by robić zdjęcia), nieodpowiednie zachowanie turystów } \\
\text { w grupie (pozowane zdjęcia, śmiechy, rozmawianie) } \\
\text { - zbyt duża liczba grup na terenie Muzeum, tłok w blokach } \\
\text { - pytania np. o to, co zostało powiedziane przed chwilą } \\
\text { - przewodnicy „blokujący” albo mówiący zbyt głośno } \\
\text { - turyści indywidualni, którzy rozpraszają, zachowują się zbyt głośno } \\
\text { - brak współpracy z przewodnikiem muzealnym }\end{array}$ \\
\hline Specyfika miejsca & $\begin{array}{l}\text { - trudny temat, wymagający umiejętności radzenia sobie z silnymi emocja- } \\
\text { mi - własnymi i zwiedzających } \\
\text { - konfrontacja z oczekiwaniami tych członków grupy, którzy oczekiwali bar- } \\
\text { dziej spersonalizowanego doświadczenia na terenie Muzeum }\end{array}$ \\
\hline Czynniki zeu & $\begin{array}{l}\text { - zimno, ciepło, słońce, deszcz } \\
\text { - nie zawsze działający sprzęt, często słaba jakość sprzętu nagłaśniającego }\end{array}$ \\
\hline
\end{tabular}

Jak wskazują wyniki ankiety, bardzo duży wpływ na jakość tłumaczenia ustnego na terenie PMAB ma doświadczenie tłumacza. Stosunkowo częstym zjawiskiem praktykowanym przez tłumaczy, którzy regularnie wykonują tłumaczenie w PMAB, jest rezygnacja z tłumaczenia na rzecz bezpośredniego oprowadzania zwiedzających. W przypadku typowego tłumaczenia ustnego tłumacz słyszy tekst tylko raz ${ }^{20}$, natomiast w przypadku PMAB za każdym razem tłumacz słyszy podobny tekst, podobne dane, podobne wyjaśnienia, a zatem jeżeli jest dodatkowo odpowiednio przygotowany pod względem merytorycznym, posiada wiedzę historyczną nie tylko o samych obozach, ale również zna szeroki kontekst historyczny, może sobie pozwolić na wcielenie się w rolę Edukatora. Główną zaletą takiego rozwiązania jest przede wszystkim oszczędność czasu, niezwykle ważna zwłaszcza w sezonie letnim, kiedy ze względu na dużą liczbę grup i opóźnienia goście bardzo często nie mają możliwości zrealizowania całej wizyty. Warto również zaznaczyć, że sam proces tłumaczenia niekiedy odbierany jest negatywnie przez zwiedzających, którzy woleliby bezpośrednie przekazywanie informacji przez Edukatora lub wcielającego się w jego rolę tłumacza.

20 E. Palka, „Verba volant, scripta manent” - czyli czym charakteryzuje się przektad ustny, „Między Oryginałem a Przekładem" 2006, nr 12, s. 245. 
Za niezbędną tłumacze uznali nie tylko znajomość stownictwa specjalistycznego, ale również ogólna biegtość jezykkowa, dzięki której wypowiedź jest płynna, a odbierany tekst znacznie łatwiejszy do przyswojenia. $\mathrm{Z}$ tego samego względu jako ważną wskazano umiejętność mówienia do ludzi (podkreślano czynniki takie jak dykcja, intonacja, emisja i barwa głosu) oraz kulturę osobistą ttumacza. Tłumacze środowiskowi często uczestniczą w bolesnych sytuacjach, a ich praca może wiązać się z dużym obciążeniem psychicznym $^{21}$. Nie bez znaczenia pozostaje więc trudny temat zwiedzania, wymagajacy od ttumacza umiejętności radzenia sobie z silnymi emocjami - wtasnymi i zwiedzających. Stres zwykle towarzyszący tłumaczeniu ustnemu nie jest więc tutaj jedynym czynnikiem psychologicznym.

Ważnym uczestnikiem tłumaczenia ustnego na terenie PMAB jest licencjonowany przewodnik, Edukator. Od niego w dużej mierze zależy powodzenie tłumaczenia, ponieważ to on decyduje, jakie informacje podać do tłumaczenia, w jakiej ilości, w jakim tempie i w jakim miejscu. Sposób oprowadzania polskich grup znacznie różni się od sposobu oprowadzania grup obcojęzycznych. W przypadku polskich grup Edukatorzy zakładają szerszą znajomość kontekstu historyczno-politycznego, mogą więc pozwolić sobie na operowanie skrótami, odwoływanie się do konkretnych wydarzeń czy nazwisk, zakładając, że będą one znane zwiedzającym. Pracując z grupami obcojęzycznymi, należy wybierać informacje w taki sposób, by przedstawiana im historia była w pełni zrozumiała. Zarówno Edukator, podając informacje, jak i tłumacz, wykonując tłumaczenie, dokonują odpowiedniej selekcji informacji. Podstawowym kryterium przy doborze informacji jest oszacowanie, w jakim stopniu zwiedzający znają nie tylko historię II wojny światowej, ale i szerszy kontekst. Braki w znajomości podstawowych faktów wpływają później na postrzeganie zarówno historii obozu, jak i historii Polski czy Polaków.

W razie jakichkolwiek wątpliwości dotyczących historii tłumacz zawsze może skonsultować się z Edukatorem, jako że nawet jeżeli nie wykonuje tłumaczenia, lecz bezpośrednio oprowadza grupę, towarzyszy mu licencjonowany przewodnik. Ankiety wykazały, że jednym z czynników najbardziej utrudniających tłumaczenie na terenie PMAB jest właśnie brak wspótpracy ze strony Edukatora oraz ci Edukatorzy i tłumacze, którzy nie potrafią dostosować się do konkretnej sytuacji, na przykład „blokując” przez długi czas ekspozycję.

Trzecim uczestnikiem tłumaczenia są zwiedzający. Na jakość tłumaczenia wpływa zarówno ich liczba, jak i zachowanie oraz nastawienie. Zwłaszcza w sezonie letnim, kiedy najwięcej osób decyduje się odwiedzić PMAB, duża liczba zwiedzających bardzo utrudnia sprawne tłumaczenie, ponieważ uniemożliwia swobodny przepływ grup. W takich momentach tłumacz sam musi dostosować się do danej sytuacji, w odpowiednim momencie ograniczyć komentarz, a w odpowiednim momencie nieco go rozszerzyć.

Ograniczenia czasowe, a zwłaszcza pośpiech, wpływają również na nastawienie zwiedzających. Za trudną tłumacze uznali konfrontację z oczekiwaniami tych cztonków

21 M. Phelan, The Interpreter's Resource, Buffalo-Toronto-Sydney 2001, s. 20-21. 
grupy, którzy spodziewali się bardziej spersonalizowanego doświadczenia na terenie muzeum. Bardzo trudno zadbać o takie doświadczenie, zwłaszcza w sezonie letnim, kiedy jednym z głównych czynników ograniczających jest czas.

Zachowanie zwiedzających, zarówno tych, dla których wykonywane jest tłumaczenie, jak i tych obecnych w innych grupach czy zwiedzających PMAB indywidualnie (bez opieki Edukatora), może działać motywująco lub, wręcz przeciwnie, może znacząco utrudnić pracę tłumacza. Tłumaczy motywuje przede wszystkim okazywanie zainteresowania omawianym tematem, natomiast czynnikiem negatywnie wpływającym na ich pracę jest niewłaściwe zachowanie zwiedzających: rozpraszanie, robienie pozowanych zdjęć, śmiechy, głośne rozmowy, odłączanie się od grupy, oddalanie się, zatrzymywanie się w celu fotografowania czy zadawanie niektórych pytań, na przykład o coś, co zostało właśnie omówione.

Czynniki zewnętrzne to przede wszystkim sprzęt techniczny (mikrofon, słuchawki, odbiorniki), który bardzo często nie działa poprawnie, oraz pogoda. Jako że znaczna część zwiedzania ma miejsce na otwartej przestrzeni, według tłumaczy kłopotliwa może być zarówno za niska, jak i za wysoka temperatura, zarówno słońce, jak i deszcz.

\subsection{Cechy tłumacza pracującego w PMAB}

Jakie cechy powinien posiadać tłumacz pracujący na terenie PMAB?

\begin{tabular}{|c|c|}
\hline Przygotowanie & $\begin{array}{l}\text { - dobrze przygotowany, najlepiej kiedy zna trasę na pamięć, łącznie z odpo- } \\
\text { wiednim słownictwem }\end{array}$ \\
\hline Cechy charakteru & $\begin{array}{l}\text { - osoba kulturalna, empatyczna (zwiedzający nie lubią ani zbyt powściągli- } \\
\text { wych, ani nadmiernie emocjonalnych stylów oprowadzania) - tolerancyjny, } \\
\text { cierpliwy, opanowany, kulturalny } \\
\text { - takt, wyczucie } \\
\text { - umiejętność psychicznego odcięcia się od tematu }\end{array}$ \\
\hline $\begin{array}{l}\text { Specyfika tłumacze- } \\
\text { nia ustnego }\end{array}$ & $\begin{array}{l}\text { - osoba potrafiąca panować nad emocjami i pracować pod presją czasu } \\
\text { - odporność na stres } \\
\text { - swoboda wypowiedzi } \\
\text { - umiejętność pracy z ludźmi } \\
\text { - zdolność szybkiego zapamiętywania }\end{array}$ \\
\hline $\begin{array}{l}\text { Specyfika pracy } \\
\text { na terenie PMAB }\end{array}$ & $\begin{array}{l}\text { - umiejętność dostosowania tempa tłumaczenia i oprowadzania do danych } \\
\text { okoliczności (np. zbyt duża liczba grup, przestoje), szybka reakcja, umiejęt- } \\
\text { ność radzenia sobie w trudnych sytuacjach } \\
\text { - panowanie nad grupą } \\
\text { - osoba zdolna do współpracy z Edukatorem }\end{array}$ \\
\hline
\end{tabular}


Kopczyński ${ }^{22}$ wymienia następujące kompetencje tłumacza ustnego:

- doskonała znajomość języka wyjściowego i docelowego;

- łatwość w wysławianiu się i empatia wobec mówcy;

- dobra pamięć i/lub umiejętność notowania (tłumaczenie konsekutywne), specjalne predyspozycje psychiczne umożliwiające podział uwagi (tłumaczenie symultaniczne);

- odporność na presję psychologiczną wynikającą z ulotnego charakteru komunikatu i obecności mówcy i odbiorców;

- umiejętność szybkiego poprawiania tłumaczenia.

Tłumacze biorący udział w badaniu również zwrócili uwagę na podobne kwestie. Według nich dobry tłumacz pracujący na terenie PMAB to tłumacz dobrze przygotowany, który zna cata trase oraz odpowiednie stownictwo. Jest przygotowany zarówno pod względem językowym, jak i merytorycznym oraz ma świadomość konieczności dostosowania przekazywanych treści do obcojęzycznej grupy. Podawane przez Edukatora informacje potrafi szybko zapamiętać i w sposób płynny i jasny przekazać grupie. Tłumacz powinien wypracować sobie własny sposób narracji, mając na uwadze, że zwiedzający nie lubia ani zbyt powściagliwych, ani nadmiernie emocjonalnych stylów opowiadania.

Praca tłumacza ustnego to praca z ludźmi, która również wymaga specjalnych umiejętności. Powinna więc wykonywać ją osoba tolerancyjna, kulturalna, opanowana i cierpliwa, zarówno w stosunku do zwiedzających, jak i do Edukatora. Na terenie PMAB tłumacz nie ma możliwości robienia notatek, mówi bezpośrednio do grupy, dodatkowo prawie cały czas znajduje się w ruchu. Zdolność współpracy z licencjonowanym przewodnikiem może również być pomocna w sytuacjach kryzysowych, kiedy tłumacz sam musi dostosować tempo thumaczenia i oprowadzania do danych okoliczności (na przykład zbyt duża liczba grup, przestoje). W trudnych sytuacjach powinien on umieć szybko reagować i wykazać się refleksem. Dobry tłumacz pracujący w PMAB to osoba, która potrafi panować nad emocjami oraz pracować pod presją czasu. Ze względu na tematykę musi również być w stanie psychicznie odciać się od tematu.

Pomimo tak szerokiego zakresu kompetencji niezbędnych w wykonywaniu zawodu tłumacza ustnego dziś zawód ten, jak zauważa Tryuk ${ }^{23}$, może wykonywać zarówno wysoko wykwalifikowany absolwent studiów tłumaczeniowych, jak również osoba, która w niewielkim stopniu opanowała znajomość języka obcego, ale jest gotowa podjąć się pracy tłumacza.

22 A. Kopczyński, Kilka uwag metodologicznych na temat studiów nad ustnym ttumaczeniem konsekutywnym, [w:] Lingwistyka stosowana i glottodydaktyka, red. F. Grucza, Warszawa 1976, s. 191; tenże, Conference Interpreting. Some Linguistics and Communicative Problems, Poznań 1980, s. 24, cyt. za: M. Tryuk, Przektad ustny konferencyjny, s. 49.

23 M. Tryuk, „Ty nic nie mów..., s. 16. 


\subsection{Dociekliwi odbiorcy}

Jakie pytania najczęściej zadają zwiedzający w trakcie zwiedzania lub po jego zakończeniu?

\begin{tabular}{|c|c|}
\hline $\begin{array}{l}\text { Pytania dotyczące } \\
\text { historii obozu }\end{array}$ & $\begin{array}{l}\text { - Co jest oryginalne, a co rekonstrukcją? } \\
\text { - Dlaczego Niemcy aż tak nienawidzili Żydów? Dlaczego Hitler nienawidził } \\
\text { Żydów? } \\
\text { - Czy ktoś zdołał uciec? } \\
\text { - Co robiły kobiety w obozie? } \\
\text { - Dlaczego ludzie nie uciekali masowo, kiedy przyjeżdżali transportami do } \\
\text { Birkenau? } \\
\text { - Czy byli świadomi, że zaraz umrą? } \\
\text { - Czy „świat” wiedział o istnieniu Auschwitz? Czy Polacy wiedzieli o obo- } \\
\text { zach zagłady? Czy Niemcy wiedzieli o obozach zagłady? Dlaczego świat nie } \\
\text { reagował na to, co się dzieje? } \\
\text { - Ile osób maksymalnie zdołał pomieścić obóz? } \\
\text { - Czy Hitler odwiedził kiedyś Auschwitz? } \\
\text { - Ilu esesmanów pilnowało więźniów? } \\
\text { - Dlaczego ludzie nie potrafili się zbuntować? }\end{array}$ \\
\hline $\begin{array}{l}\text { Pytania dotyczące } \\
\text { historii po II wojnie } \\
\text { światowej }\end{array}$ & $\begin{array}{l}\text { - Czy esesmani, którzy tam pracowali, czuli później skruchę, czy ich osądzono? } \\
\text { - Która okupacja, niemiecka czy sowiecka, była gorsza? }\end{array}$ \\
\hline $\begin{array}{l}\text { Pytania doty- } \\
\text { czące stosunków } \\
\text { polsko-niemieckich }\end{array}$ & $\begin{array}{l}\text { - Czy przyjeżdża dużo grup niemieckich? } \\
\text { - Czy my jako Polacy czujemy do Niemców nienawiść? }\end{array}$ \\
\hline $\begin{array}{l}\text { Pytania dotyczą- } \\
\text { ce pracy na terenie } \\
\text { PMAB }\end{array}$ & - Jak Edukatorzy i tłumacze radzą sobie emocjonalnie ze swoją pracą? \\
\hline
\end{tabular}

Konspekt oprowadzania oraz ograniczony czas sprawiają, że podczas standardowego zwiedzania goście mają szansę zapoznać się tylko z wybraną częścią historii obozu Auschwitz-Birkenau, poznają najważniejsze fakty oraz mogą zobaczyć część ekspozycji zbiorów muzealnych. Tłumacz dokonuje selekcji informacji, na przykład streszczając niektóre fragmenty lub, przeciwnie, dodając informację, uzupełniając tekst oryginału w taki sposób, by był on bardziej zrozumiały dla odbiorcy, zwłaszcza w przypadku istniejących różnic międzykulturowych ${ }^{24}$. Ograniczony, przede wszystkim względami czasowymi, zasób informacji, które otrzymują zwiedzający, zmusza ich do zadawania pytań Edukatorowi w celu pogłębienia tematu.

Udzielane odpowiedzi wychodzą poza ramy opowiadanej historii obozu, zadaniem Edukatora i tłumacza jest tutaj przedstawienie obecnych relacji między wspomnianymi narodami, wyjaśnienie stosunków między nimi oraz zwrócenie uwagi na cel funkcjonowania PMAB w budowaniu społeczeństwa otwartego. Pytania zadawane przez

24 E. Palka, „Verba volant..., s. 248. 
zwiedzających pokazują tłumaczowi, jak obcokrajowcy postrzegają zjawisko obozów koncentracyjnych i zagłady, a zatem otwierają tłumacza na inny punkt widzenia na polską historię.

\section{PODSUMOWANIE}

Tłumacze ustni pojawiali się i wciąż pojawią w nowych rolach, często jednak ich praca nie jest doceniana. Jak zauważa Tryuk ${ }^{25}$, za dużo jest dzisiaj krytyki wobec ttumaczy, a za mato prób docenienia ich rzeczywistej roli $w$ ztożonych relacjach wspótczesnego świata [...]. Ttumaczenie jest zawsze zanurzone w kontekście spotecznym i politycznym i w tym wtaśnie sensie ma wymiar etyczny. Pomimo różnych zadań, jakie napotykają tłumacze ustni, zazwyczaj łączy je jeden cel - ułatwienie komunikacji. Nawet jeżeli tłumacz doskonale opanował umiejętności językowe, powinien również zwrócić uwagę na inne czynniki wpływające na proces tłumaczenia, np. na kontekst społeczny czy otoczenie, w którym ma miejsce dane tłumaczenie ${ }^{26}$. Analizowane tłumaczenie odbywa się na terenie byłego obozu Auschwitz-Birkenau, dlatego od tłumacza ustnego wymaga się przede wszystkim rzetelnego przekazywania informacji, które umożliwi zwiedzającym wyciągnięcie własnych wniosków i samodzielne zmierzenie się z jedną z „najciemniejszych kart historii”. Aby było to możliwe, cały proces tłumaczenia powinien przebiegać sprawnie i płynnie, na co wpływ, poza oczywistymi czynnikami zewnętrznymi, mają zarówno osoba tłumacza i jego osobiste kompetencje, jak i inne postaci uczestniczące w procesie tłumaczenia, które stale na siebie oddziałują: Edukator i zwiedzający.

Edukator oraz tłumacz powinni przedstawić historię byłego obozu Auschwitz-Birkenau, sytuując podawane informacje w odpowiednim kontekście, oraz wyjaśnić, w miarę możliwości, sporne kwestie czy rozwiać wątpliwości. Edukator jest specjalistą, wykwalifikowanym przewodnikiem, dlatego też tłumacz powinien potrafić wykorzystać jego wiedzę i odpowiednio dostosować przekazywane treści do zagranicznych gości. Problemy, z jakimi muszą poradzić sobie tłumacze, wynikają przede wszystkim ze specyfiki miejsca, nierzadko związane są również z charakterystycznym językiem obozowym czy koniecznością dostosowania się do ograniczonego czasu wizyty. Duża liczba pytań zadawanych przez zwiedzających sugeruje, że PMAB jest dla nich miejscem, w którym szukają odpowiedzi na wiele pytań związanych z tematem II wojny światowej oraz niemieckich obozów koncentracyjnych i zagłady.

Tłumacze ustni biorą udział $\mathrm{w}$ dialogu międzykulturowym, realizując założenia PMAB. Chociaż termin „kulturowy pośrednik” został po raz pierwszy wprowadzony w 1981 roku przez Stephena Bochnera w jego Mediating Person oraz Cultural Identity, już w 1975 roku George Steiner podkreślał rolę tłumacza jako dwujęzycznego

25 M. Tryuk, „Ty nic nie mów..., s. 172.

26 C. Angelelli, Revisiting the Interpreter's Role. A Study of Conference, Court, and Medical Interpreters in Canada, Mexico, and the United States, Amsterdam-Philadelphia 2004, s. 7. 
pośrednika pomiędzy członkami dwóch jednojęzycznych społeczności ${ }^{27}$. Przed tłumaczami stawia się nowe cele, oprócz przekazywania historii, przy pomocy Edukatorów, biorą oni udział w edukacji oraz budowie społeczeństwa otwartego. $\mathrm{O}$ takiej roli PMAB i pracujących tam osób pisze dyrektor Muzeum w sprawozdaniu za rok 2015: Siedemdziesiąt lat po wojnie nasz wspótczesny świat coraz bardziej niepokoi. Wszyscy widzimy i odczuwamy narastanie populizmu, ksenofobii, nacjonalizmu, antysemityzmu, terroryzmu i wojen... Tymczasem wiemy dobrze - aż za dobrze - dokąd prowadzi zaślepiająca moc nienawiści. Dlatego tak ważne jest, by - zwtaszcza mtode pokolenia - poczuly site krzyczacego przekazu, jaki ptynie z Auschwitz, z tragedii Szoa i obozów koncentracyjnych. To te pokolenia będa już niebawem dokonywaty swoich dojrzatych wyborów życiowych. One musza umieć przeciwstawić się nienawiści, zanim jej spirala nie rozkręci na nowo huraganu wyniszczenia wśród naszych spoteczeństw ${ }^{28}$. Liczba turystów zagranicznych odwiedzających Polskę stale rośnie, dlatego widoczny jest wzrost zapotrzebowania na tłumaczy podejmujących pracę w miejscach, które zagraniczni turyści odwiedzają w celach edukacyjnych. Warto podkreślić, że Państwowe Muzeum Auschwitz-Birkenau to tylko jedno z miejsc, gdzie tłumacz ustny jest tak wyraźną postacią biorącą udział w procesach zachodzących na styku kultur, narodowości czy religii. Przeprowadzone badanie i uzyskane wyniki otwierają pole do dalszych dyskusji na temat tłumaczeń wykonywanych w celach edukacyjnych.

\section{BIBLIOGRAFIA}

Angelelli C., Revisiting the Interpreter's Role. A Study of Conference, Court, and Medical Interpreters in Canada, Mexico, and the United States, Amsterdam-Philadelphia 2004.

Apter E., Against World Literature. On the Politics of Untranslatability, London 2013.

Baigorri Jalón J., La interpretación de conferencias. El nacimiento de una profesión, de París a Núremberg, Granada 2000.

Chrobak M., Ttumacze pielgrzymów, [w:] tejże, Między światami. Ttumacz ustny oraz komunikacja międzykulturowa w literaturze odkrycia i konkwisty Ameryki, Kraków 2012.

Degen S., The Illusion of Authenticity: The Translation of Video Testimonies with Survivors of National Socialist Terror for Use in Education Work, [w:] Interpreting in Nazi Concentration Camps, red. M. Wolf, London 2016.

Dragovic-Drouet M., The Practice of Translation and Interpreting during the Conflicts in the Former Yugoslavia (1991-1999), [w:] Translating and Interpreting Conflict, red. M. SalamaCarr, Amsterdam-New York 2007.

Footitt H., Kelly M., Languages at War. Policies and Practices of Language Contacts in Conflict, Basingstoke 2012.

27 D. Katan, Translating Cultures. An Introduction for Translators, Interpreters and Mediators, Manchester 1999, s. 16.

28 Sprawozdanie 2015, red. B. Bartyzel, P. Sawicki, Oświęcim 2016, s. 4, Auschwitz-Birkenau. Były Niemiecki Nazistowski Obóz Koncentracyjny i Zagłady, [online] http://www.auschwitz.org/muzeum/ sprawozdania-roczne/. 
Gile D., Basic Concepts and Models for Interpreter and Translator Training, Amsterdam-Philadelphia 1995.

Inghilleri M., The Ethical Task of the Translator in the Geo-Political Arena: From Iraq to Guantánamo Bay, „Translation Studies” 2008, vol. 1, nr 2, http://dx.doi.org/10.1080/ 14781700802113556.

Interpreting in Nazi Concentration Camps, red. M. Wolf, New York 2016.

Katan D., Translating Cultures. An Introduction for Translators, Interpreters and Mediators, Manchester 1999.

Kopczyński A., Kilka uwag metodologicznych na temat studiów nad ustnym ttumaczeniem konsekutywnym, [w:] Lingwistyka stosowana i glottodydaktyka, red. F. Grucza, Warszawa 1976.

Kopczyński A., Conference Interpreting. Some Linguistics and Communicative Problems, Poznań 1980.

Kuhiwczak P., Intertwining Memory and Translation. The Grammar of Survival. How do We Read Holocaust Testimonies, [w:] Translating and Interpreting Conflict, red. M. Salama-Carr, Amsterdam-New York 2007.

Lederer M., La traduction simultanée. Fondements théoriques, Paris 1981.

Levi P., The Drowned and the Saved, London 1988.

Mata encyklopedia przektadoznawstwa, red. U. Dąmbska-Prokop, Częstochowa 2000.

Moser-Mercer B., Quality in Interpreting: Some Methodological Issues, „The Interpreters' Newsletter" 1996, nr 7.

Muzeum $w$ datach, Auschwitz-Birkenau. Były Niemiecki Nazistowski Obóz Koncentracyjny i Zagłady, [online] http://www.auschwitz.org/muzeum/historia-muzeum/muzeum-w-datach, 5 X 2017.

Oschlies W., „Lagerszpracha”. Zur Theorie und Empirie einer KZ-spezifischen Soziolinguistik, "Zeitgeschichte” 1985, vol. 13, nr 1.

Palka E., „Verba volant, scripta manent” - czyli czym charakteryzuje się przektad ustny, „Między Oryginałem a Przekładem" 2006, nr 12.

Phelan M., The Interpreter's Resource, Buffalo-Toronto-Sydney 2001.

Pöchhacker F., Introducing Interpreting Studies, London-New York 2004.

Pym A., Humanizing Translation History, „Hermes. Journal of Language and Communication Studies" 2009, nr 42, https://doi.org/10.7146/hjlcb.v22i42.96845.

Rodzaje zwiedzania, Auschwitz-Birkenau. Były Niemiecki Nazistowski Obóz Koncentracyjny i Zagłady, [online] http://www.auschwitz.org/zwiedzanie/przewodnicy/, 5 X 2017.

Sprawozdanie 2015, red. B. Bartyzel, P. Sawicki, Oświęcim 2016, Auschwitz-Birkenau. Były Niemiecki Nazistowski Obóz Koncentracyjny i Zagłady, [online] http://www.auschwitz. org/muzeum/sprawozdania-roczne/, 10 X 2017.

Sprawozdanie 2016, red. B. Bartyzel, P. Sawicki, Oświęcim 2017, Auschwitz-Birkenau. Były Niemiecki Nazistowski Obóz Koncentracyjny i Zagłady, [online] http://www.auschwitz. org/muzeum/sprawozdania-roczne/, 10 X 2017.

StahuljakZ., Violent Distortions: Bearing Witness to the Task of Wartime Translators, „, TTR: Traduction, Terminologie, Rédaction”2000, vol. 13, nr 1, http://dx.doi.org/10.7202/037392ar. Stahuljak Z., War, Translation, Transnationalism: Interpreters in and of the War (Croatia, 19911992), [w:] Critical Readings in Translation Studies, red. M. Baker, London 2010. 
Świebocka T., Pinderska-Lech J., Mensfelt J., Auschwitz-Birkenau. Historia i teraźniejszość, Oświęcim 2010.

Translation Studies. Perspectives on an Emerging Discipline, red. A. Riccardi, Cambridge 2002. Tryuk M., Przektad ustny środowiskowy, Warszawa 2006.

Tryuk M., Przektad ustny konferencyjny, Warszawa 2007.

Tryuk M., O ttumaczach, prawnikach, lekarzach i urzędnikach. Teoria i praktyka ttumaczenia środowiskowego w Polsce, Warszawa 2010.

Tryuk M., „Ty nic nie mów, ja będę ttumaczyt”. O etyce w ttumaczeniu ustnym, Warszawa 2012. Tryuk M., Interpreting and Translating in Nazi Concentration Camps during World War II, „Linguistica Antverpiensia. New Series: Themes in Translation Studies” 2016, nr 15.

Wesołowska D., Stowa z piekta rodem. Lagerszpracha, Kraków 1996.

Yad Vashem - The World Holocaust Remembrance Center, [online] http://www.yadvashem.org/, $5 \times 2017$.

Marta PALECZNA - tłumaczka przysięgła języka hiszpańskiego, doktorantka na Wydziale Filologicznym Uniwersytetu Jagiellońskiego. 